Review

\title{
Sustainability in City-Regionalism as Emergent Practice: The Case of the BRICS
}

\author{
Philip Harrison
}

check for updates

Citation: Harrison, P. Sustainability in City-Regionalism as Emergent Practice: The Case of the BRICS. Sustainability 2021, 13, 4721. https://doi.org/10.3390/su13094721

Academic Editor: Stefan Greiving

Received: 16 March 2021

Accepted: 31 March 2021

Published: 23 April 2021

Publisher's Note: MDPI stays neutral with regard to jurisdictional claims in published maps and institutional affiliations.

Copyright: (C) 2021 by the author. Licensee MDPI, Basel, Switzerland. This article is an open access article distributed under the terms and conditions of the Creative Commons Attribution (CC BY) license (https:// creativecommons.org/licenses/by/ $4.0 /)$.
School of Architecture and Planning, University of the Witwatersrand, Johannesburg 2050, South Africa; Philip.harrison@wits.ac.za

\begin{abstract}
Sustainability concerns transgress jurisdictional boundaries compelling multi-scalar and inter-jurisdictional responses. The city-region is one of the scales at which governance actors may mobilise for sustainability and this is now recognised in literatures on integrated food systems, for example. However, within the mainstream debates on city-regions, sustainability as a motivation for inter-jurisdictional governance is still given scant attention. This paper considers the extent to which sustainability is present as a driver towards city-region governance, using countries within the still underexplored BRICS cluster as cases studies. The paper shows that in practice the connection between environmental sustainability and city regionalism remains mainly limited and fractious. In all cases, however, there are emergent connections which offer the potential for stronger connections. Most importantly, public reaction to a mounting environmental crisis in the BRICS is obliging the actors of governance, concerned with sustaining their public legitimacy, to establish or strengthen inter-jurisdictional and collaborative relationships across city-regions. There are however significant limits to these endeavours, especially where levels of social trust are low, or where sustainability problems are rooted within unsustainable national growth paths.
\end{abstract}

Keywords: city-region; urban sustainability; environmental politics; environmental governance; BRICS; comparative method

\section{Introduction}

The stretching of the urban landscape across multiple governmental jurisdictions presents confounding challenges of coordination and collective action in addressing sustainability concerns. Earlier writing on sustainability focussed on the global, national, and local scales of action but there is now growing attention to the multi-scalar nature of environmental governance [1,2], and to intervening scales such as the city-region that do not correspond to the traditional levels of the governmental hierarchy [3-7].

Sustainability literatures have drawn on the idea of a city-region in offering an integrated food systems approach [4,6,7]; exploring strategic sites for energy transitions [3]; and investigating policy and planning tensions across the objectives of competitiveness and sustainability [5]. In the city-region literatures, however, there is still very limited reference to the sustainability dimension. In the mainstream literature there are two dominant threads to the discussion. First, there is a literature that focuses on the economic rationale for the development of city-regions, emphasizing the logics of agglomeration, growth, innovation, and competition [8,9], and here there is little, if any, reference to sustainability as a motivation or logic for city-region governance.

There is, however, a countervailing literature that has emphasized the political construction of the city-region and diversity of drivers toward city-region governance [10-12]. Jonas and Ward represent this position, for example, when arguing that "city-regions ought to be conceptualized as contingent products of practical acts of political construction and, therefore, as necessarily variable according to political interests and thus indeterminate territorial formations" [12] While this literature has not focused on the sustainability rationale 
for city-region governance, emphasizing rather the political interests and conflicts behind city-region formation, it acknowledges sustainability among a multiplicity of motivations for city-region governance which may overlap or exist in parallel with each other. In addition to the territorial interests of political players these drivers may include social demands for a redistribution of public benefits; the spatial integration agendas of planners; and a concern by environmentalists to address externalities and spillovers through collective action on a regional basis [11-13].

There is an emergent third strand of work which acknowledges that concerns with sustainability have not seeped deeply into the policies and debates around city-regions but argues that the scale of the city-region invites collective learning and practices that would support sustainability [14,15]. Wheeler, for example, writes of the obstacles and limitations of integrating environmental concerns in city-region scale governance, but goes on to propose "a vision of sustainable regionalism" [15].

In the sections below, the need for such a vision is implicit, but the focus is on understanding the existing links between city regionalism and sustainability drivers within selected contexts. This follows Addie and Keil who call for a careful exploration of "real existing city regionalism" which acknowledges that "regionalism is neither a mere normative ideational construct nor a set of predictable practices, but a contested product of discourses (talk), territorial relationships (territory) and technologies (both material and of power)" [16].

The use of BRICS cluster to provide these contexts is intended as a contribution to broadening the geographic foundation of the literature. While the BRICS have attracted some attention in the literatures on both city-regions and urban sustainability, they remain significantly underrepresented in scholarly work, given the reality that 40 percent of cities on the database of the Population Division of the Department of Economic and Social Affairs of the United Nations, and five of the ten largest city-regions globally, fall within this grouping of five countries [17]. The BRICS are of course a diverse grouping in terms of physical size, population, economic structure, growth, constitutional arrangement, political culture, and more, but I follow an approach in which comparison is attentive to repetition, connection, and difference [18].

This review article draws on scholarship and policy-related work from each of the BRICS, much of which is still to be adequately integrated into the dominating literatures. The author has spent time in the major city-regions across the BRICS, observing, reading, and conducting interviews, and this provides the underpinning contextual knowledge. Thirty-five in-depth qualitative interviews were conducted in cities across the BRICS in the period 2016 to 2019 as well as an analysis of the grey literatures and scholarly work within the respective contexts. This empirical work provides the knowledge setting on city-region governance that underpins the focus of this review article on the sustainability dimension.

The article continues below with three comparative tables that provide a synoptic description of the developmental, political and sustainability context of the BRICS before focusing in turn on each country, following the letter order in the acronym. The countrylevel discussions focus on the nature of city-region governance and its relationship to sustainability motivations and drivers.

\section{Developmental, Political and Sustainability Context}

Table 1 reveals the extraordinary diversity of the BRICS. It shows a geopolitical cluster of countries with immense variation in population and economic size but also of considerable differences in developmental status and human condition. The BRICS includes one country within the high-income category (Russia), three in the middle-income category (China, Brazil and South), and one that is categorized a low-income (India). It also includes levels of urbanization ranging dramatically from $34 \%$ in India to $86.6 \%$ in Brazil, (although India's urban population is growing significantly faster than that of Brazil). 
Table 1. Comparative indicators of demography, economic and urbanization for the BRICS (Sources: UNDP, IMF, World Bank).

\begin{tabular}{|c|c|c|c|c|c|}
\hline Indicators & Brazil & Russia & India & China & $\begin{array}{l}\text { South } \\
\text { Africa }\end{array}$ \\
\hline $\begin{array}{l}\text { Population size in millions (est. } \\
\text { July 2019) }\end{array}$ & 211.1 & 145.9 & 1366.4 & 1433.8 & 58.6 \\
\hline Size of GDP in USD trillion (2018) & 2.26 & 1.75 & 3.16 & 15.54 & 0.39 \\
\hline GDP per capita in USD & 10693 & 12.026 & 2.309 & 10.841 & 6.606 \\
\hline $\begin{array}{l}\text { Population living below the } \\
\text { income poverty line PP } \$ 1.90,2018\end{array}$ & 4.4 & - & 21.2 & 0.5 & 18.9 \\
\hline $\begin{array}{l}\text { Level of income inequality (Gini } \\
\text { Coefficient), } 2018\end{array}$ & 53.9 & 37.5 & 35.2 & 37.8 & 63.0 \\
\hline $\begin{array}{l}\text { Gender equality index ( } 0.0 \text { is } \\
\text { perfect equality, } 1.0 \text { perfect } \\
\text { inequality) }\end{array}$ & 0.408 & 0.225 & 0.488 & 0.168 & 0.406 \\
\hline $\begin{array}{l}\text { Human Development Index, } 2019 \\
\text { (world }=0.737 \text { ) }\end{array}$ & 0.765 & 0.824 & 0.645 & 0.761 & 0.709 \\
\hline Level of Urbanisation (2018) & 86.6 & 74.4 & 34.0 & 59.2 & 66.4 \\
\hline $\begin{array}{l}\text { Size of urban population in } \\
\text { millions (2018) }\end{array}$ & 182.5 & 107.2 & 460.8 & 837.0 & 38.1 \\
\hline $\begin{array}{l}\text { Annual urban percentage } \\
\text { growth-2015-2020 }\end{array}$ & 1.05 & 0.18 & 2.37 & 2.42 & 1.97 \\
\hline
\end{tabular}

As Table 2 indicates, the BRICS includes federal, unitary, and hybrid states, with political systems that range from single-party authoritarian to multi-party democratic. The position of local government also varies significantly across the BRICS from contexts where local government is constitutionally embedded and quite autonomous to those where local government is fragile and dependent for its survival on the whims of higher levels of government.

Table 2. The Structures and Systems of Governance across the BRICS.

\begin{tabular}{|c|c|c|c|c|c|}
\hline Dimensions & Brazil & Russia & India & China & South Africa \\
\hline $\begin{array}{c}\text { Constitutional } \\
\text { arrangement }\end{array}$ & Federal State & $\begin{array}{l}\text { Federal State but } \\
\text { de facto tendencies } \\
\text { towards a unitary } \\
\text { arrangement }\end{array}$ & Federal State & Unitary State & $\begin{array}{c}\text { A Unitary State but } \\
\text { with some aspects } \\
\text { of federalism }\end{array}$ \\
\hline $\begin{array}{l}\text { Classification of } \\
\text { political system * }\end{array}$ & Flawed Democracy & Authoritarian & Flawed Democracy & Authoritarian & Flawed Democracy \\
\hline Political parties & $\begin{array}{l}\text { Multiparty with } \\
\text { high levels of } \\
\text { political } \\
\text { fragmentation }\end{array}$ & $\begin{array}{c}\text { Officially } \\
\text { multi-party but } \\
\text { with dominance of } \\
\text { a single party }\end{array}$ & $\begin{array}{l}\text { Multiparty with } \\
\text { main parties } \\
\text { competing } \\
\text { nationally and } \\
\text { many regional } \\
\text { parties }\end{array}$ & $\begin{array}{c}\text { Monopoly of } \\
\text { power by } \\
\text { Communist Party } \\
\text { of China }\end{array}$ & $\begin{array}{l}\text { Multiparty with } \\
\text { the dominance of a } \\
\text { single party } \\
\text { in decline }\end{array}$ \\
\hline $\begin{array}{l}\text { Position of local } \\
\text { government }\end{array}$ & $\begin{array}{l}\text { Constitutionally } \\
\text { recognised unit of } \\
\text { the federation with } \\
\text { strong powers }\end{array}$ & $\begin{array}{c}\text { Autonomy } \\
\text { increasingly } \\
\text { constrained and } \\
\text { asymmetrical } \\
\text { powers across } \\
\text { the federation }\end{array}$ & $\begin{array}{l}\text { Dependent on } \\
\text { State-level } \\
\text { government and } \\
\text { generally weak } \\
\text { powers }\end{array}$ & $\begin{array}{l}\text { Embedded within } \\
\text { a strong national } \\
\text { hierarchy, but with } \\
\text { high levels of } \\
\text { decentralisation }\end{array}$ & $\begin{array}{l}\text { Protected in } \\
\text { national } \\
\text { constitution but } \\
\text { powers limited }\end{array}$ \\
\hline
\end{tabular}

${ }^{*}$ Note: The classification of political system is drawn from the Democracy Index of the Economist Intelligence Unit.

Table 3 provides a comparative account of sustainability indicators for the BRICS. It reveals a cluster of countries with severe but varying sustainability challenges. Russia, China, and South Africa, for example, have very high levels of carbon dependency in their economies and are also high per capita emitters of greenhouse gases. Brazil, however, is 
better placed because of the significance of hydropower in generating electricity while the relative low figures for India has to do with the lower levels of energy use in this low-income country. India and China face severe health challenges because of air pollution, while India and South Africa have higher-than-global averages of mortality because of unsafe water supply and poor sanitation. India, South Africa, and China, face major challenges in terms of water security (although parts of Brazil have also experienced severe droughts in the recent past). China has a high global footprint in terms of per capita material consumption, with Brazil and Russia also above the global average. China and India have afforestation programs which have significantly increased the area under trees, but South Africa faces severe land degradation, and the rapid deforestation in Brazil is of a scale that has serious consequences globally.

Table 3. Sustainability Indicators for the BRICS (Source: UNDP).

\begin{tabular}{|c|c|c|c|c|c|c|}
\hline Indicator & Brazil & Russia & India & China & $\begin{array}{l}\text { South } \\
\text { Africa }\end{array}$ & World \\
\hline $\begin{array}{l}\text { Fossil Fuels as a Percentage of } \\
\text { Total Energy Use, 2013-2015 }\end{array}$ & 59.1 & 92.1 & 73.6 & 87.7 & 86.8 & 80.6 \\
\hline $\begin{array}{l}\text { Carbon Dioxide Emissions } \\
\text { per Unit of GDP, } 2017\end{array}$ & 0.15 & 0.48 & 0.26 & 0.45 & 0.62 & 0.26 \\
\hline $\begin{array}{l}\text { Mortality atTributed to } \\
\text { Household and Ambient Air } \\
\text { Pollution per 100,000 of } \\
\text { Population, } 2016\end{array}$ & 30 & 49 & 184 & 113 & 87 & 114 \\
\hline $\begin{array}{l}\text { Mortality atTributed to } \\
\text { Unsafe Water and Inadequate } \\
\text { Sanitation per } 100,000 \text { of } \\
\text { Population, } 2016\end{array}$ & 1.0 & 0.1 & 18.6 & 0.6 & 13.7 & 11.7 \\
\hline $\begin{array}{c}\text { Freshwater Withdrawal as a } \\
\text { Percentage of Total } \\
\text { Renewable Water Resources, } \\
\text { 2007-2017 }\end{array}$ & 0.8 & 1.4 & 33.9 & 20.9 & 37.7 & 7.7 \\
\hline $\begin{array}{c}\text { Domestic Material } \\
\text { Consumption per Capita, } 2017 \\
\text { (tonnes) }\end{array}$ & 17.4 & 16.9 & 5.5 & 25.0 & 11.3 & 12.3 \\
\hline $\begin{array}{c}\text { Degraded Land as a } \\
\text { Percentage of Total Land } \\
\text { Area, } 2015\end{array}$ & 27.0 & 6.0 & 30.0 & 27.0 & 78.0 & 20.0 \\
\hline $\begin{array}{c}\text { Percentage Change in Forest } \\
\text { Area, 1990-2016 }\end{array}$ & 0.8 & -9.9 & +10.8 & +33.6 & 0.0 & -3.0 \\
\hline
\end{tabular}

The tables provided above refer to a national context, but this is a necessary framing for a consideration of governance challenges at the scale of major urban agglomerations or city-regions. Each country in the BRICS includes city-regions which are of a significant scale in global terms although the nature of the agglomerations is highly diverse. China has three mega agglomerations with populations of over 100 million each, depending on boundary definitions - that is, the National Capital Region, the Yangtze River Delta, and the Greater Bay Area (also referred to as the Pearl River Delta). This is in addition to many other medium- and smaller-sized agglomerations. The Yangtze River Delta has an economy equivalent to that of Germany and Japan. India has a formally designated National Capital Region with a population of over 40 million and an economy as large as that of Argentina. Although without formal recognition, the Greater Mumbai Region (also referred to as Golden Triangle of Maharashtra) is referred to in international literatures as a Global City-Region and has a population of over 50 million and an economy as large as that of South Africa. Other major cities, including Kolkata, Chennai, and Bangalore, are metropolitan agglomerations that may also be considered as the hubs of wider city-regions. 
The officially recognized São Paulo Metropolitan Region has a population of around 24 million and an economy the size of Vietnam. However, there is increasing reference to a São Paulo Macro Metropolis with a population of over 30 million, and even to a Mega City-region, connecting in an extended corridor to the Rio de Janeiro Metropolitan Region with its' population of 13 million. The Moscow Urban Agglomeration has a population of over 20 million and is the core of the national urban economy. The Saint Petersburg Urban Agglomeration is modest in global terms with a population of only 6 million. However, Saint Petersburg arguably forms part of greater transnational Baltic agglomeration extending as far as Helsinki in Finland and Tallinn in Estonia. South Africa is the minnow in the BRICS, but it does have a moderately sized city-region which is the core of its national economy. The Gauteng City-Region, focused on the cities of Johannesburg, Tshwane (Pretoria), and Ekurhuleni, has a population of around 15 million, dependent on boundary definition, and accounts for around one-third of national economic output.

All these large agglomerations face immense challenges in terms of the sustainable use of critical natural resources, and in terms of pollution and the contributions to, and impacts of, global changes. The National Capital Regions in China and India, Greater São Paulo in Brazil, and the Gauteng City-Region in South Africa, face severe water security challenges, while the large agglomerations in China and India have among the world's highest levels of air pollution. There is high dependence on fossil fuels for electricity and fuel in the agglomerations of Russia, China, India and South Africa, and traffic congestion in most cities of the BRICS. Potable water and sanitation are persisting challenges in the slums and informal settlements of India, Brazil, and South Africa. These are all challenges that require collaborative agglomeration-wide interventions, if not at a wider scale, but the existing practices of collaboration are limited and variable and, as shown below, the possibilities for expanded action are constrained (and, sometimes, enabled) by political cultures, constitutional arrangements, embedded path dependencies, and relational capabilities.

\section{The BRICS Case Studies}

\subsection{The Brazilian Federation}

Brazil's political culture is a curious combination of legalism, formalism, informality, patronage, authoritarian paternalism, and commitments to democratic citizenship [19-21]. There is also an enduring tension between a committed localism, indicated in the zealous attempts to protest the autonomy of local authorities, and a 'strong man' politics which underpins Brazil's presidentialism [20,21].

This admixture has complicated institutional formation and has made the construction of city-region governance-referred to in Brazil as 'metropolitan' and 'extendedmetropolitan' governance- - a fractious process. Ribeiro and dos Santos Junior conclude that:

"The political elites appear incapable of mobilizing themselves around an institutionbuilding project that takes advantage of the productive forces and the potential concentrated in the Brazilian complex, rich and diversified metropolitan system, a project that could avoid the environmental and social disasters seen today in most of Brazil's metropolitan regions" [22].

There have however been historical attempts to achieve coordinated action across urban agglomerations. In the 1970s, the military regime designated Região MetropolitanaRMs (metropolitan regions), and set up metropolitan-scale structures, as an attempted 'technical fix' to the growing challenges of Brazil's then rapidly expanding urban agglomerations. These were top-down structures appointed by State Governors but they came with flows of federal funding for housing and infrastructure. However, even as these structures were constituted from the late 1970s, the military regime was crumbling in the face of economic crisis and civic protests [23].

In the transition to democracy which culminated in the new national constitution of 1988, the metropolitan scale was largely ignored. Metropolitan governance was associated with authoritarian rule, and the constitutional imperative at the time was to protect the 
powers of local authorities. The constitution was thus overwhelmingly decentralist, with the dominant trend in the early democratic era towards greater institutional fragmentation. The regional structures which did exist were either disbanded or, as in the case of EMPLASA in the São Paulo MR, "hollowed out" [23].

However, in the past twenty years or so, there has been a gradual and uneven shift back towards limited forms of metropolitan governance. The celebrated Estatuto da Cidade (Statute of the Cities), 2001, said nothing of metropolitan-scale intervention or regulation but in the early 2000s some state governments-most notably Minas Gerais with Belo Horizonte as its capital—reintroduced provisions for metropolitan structures. However, even these limited forms of institutional collaboration were challenged, and it took until 2013 for the Federal Supreme Court to confirm that it fell within the competence of State governments to designate MRs [24]. More organically, some local governments collaborated at sub-metropolitan level within inter-municipal consortia, the most well-known alliance being the Inter-Municipal Consortium for the ABC Sub-Region of Greater São Paulo [23].

In January 2015 President Rousseff signed the Estatuto das Metrópole (Statute of the Metropolis) into law, which referred to the "inter-federative governance" of MRs, providing for structures that would bring all units of the federation together in collaborative arrangements [24]. This gave a new lease of life to ailing metropolitan structures such as EMPLASA and raised the hopes of a new balance evolving between local powers and regional collaboration.

However, a rightwards political shift in Brazil soon strangled the process. The election of the right-wing populist, Jair Bolsonaro, to the national presidency in 2018, and of similarminded Governors and Mayors across other parts of Brazil, brought many of the new metropolitan experiments to a premature end. In May 2019, for example, EMPLASA was disbanded and its functions transferred to a state government department.

Nevertheless, while political support for metropolitan-scale, or inter-federative, planning fluctuates, Brazil's large urban agglomerations have problems that require practical solutions, and this has prompted some sector specific attempts at city-region wide collaboration. Water is the "ultimate survival good" [20], and addressing water security has indeed produced forms of "inter-jurisdictional collective action" [25].

In Brazil, "urban water problems confound prevailing models of decentralization and local participation because both their causes and their effects are inexorably regional" [20]. In response, Brazil's National Water Resource Management System (NWRRM), set up in terms of Law 9433, 1997, recognizes the inter-federative nature of water management and provides for a cluster of deliberative water-related bodies [20,26].

In the case of the São Paulo, water supply comes partly from the Alto Tietê Basin within the territory of its' metropolitan region, but also partly from three river basins beyond the metropolitan region through a massive inter-basin water transfer scheme known as the Cantareira system. The collaborative structures set up for the Alto Tietê basin bring together the state water agency with governments, community- and other groupings of civil society; universities; and the private sector. It is, arguably, a practical form of city-region governance but it is also an extremely complex form of collaborative governance in a region where there is an intense conflict between the irregular settlement which provides a substantial proportion of the urban poor in metropolitan region with access to land, and the need to preserve water catchments [20,26]

The Water Act was framework legislation and left "a system yet to be constructed" [20]. The process of construction has been extremely difficult with highly complex struggles for power and influence within the deliberative structures that have been set up [20]. Additionally, the severe drought of 2013-2015 allowed the state government to re-centralize much of the decision-making around water, undermining city regionalism as an approach [26]. Abers and Keck explain that the "the attempt to create the new system ran head on into some of the most embedded characteristics of Brazilian politics" [20].

The other half of São Paulo's water supply requires inter-basin transfers and is a reminder that city-regions often create demand for resources that cannot be met within the 
region itself and require systems of governance at an expanded scale. Inter-basin transfers began in the 1970s and at that time it was merely a technical challenge as the supplying river basin had sufficient water to export. The politics of water transfer have however become much more complicated as the water-donating catchments have also urbanised and have their own increasing demand for water, while there is also growing competition from the hydropower sector [26].

Brazil's experience certainly offers complexity to the discussion. Historically produced ideological orientations have made it difficult to create, consolidate and maintain structures of city-region scale governance although practical necessity has impelled regional-scale collaboration in sectors including water. These collaborations remain however riven with competing interests and conflict.

\subsection{The Russian Federation}

The challenge of collective action across city-regions in Russia has multiplied in the post-Soviet era, as the primary mechanism for territorial coordination, the Communist Party of the Soviet Union (CPSU), disintegrated at the same time as an emerging market economy triggered the rapid physical expansion of cities.

In the case of Saint Petersburg, the First Secretary to the Leningrad Oblast was, historically, also the First Secretary to Leningrad City, and there was a Joint Leningrad Regional Communist Party Committee. A joint Master Plan for City and Oblast (the authority for the region surrounding the city) was in fact prepared in 1985 [27]. However, in the early post-Soviet period, Saint Petersburg was effectively freed from its obligation to the region and could focus on its own positioning as a nationally and globally competitive region, although with increasingly disjointed developments having negative consequences for the quality of the natural and built environments [28].

With its far greater scale, meaningful collaboration between the City of Moscow and the Moscow Oblast was always more complicated. The cross-membership on party structures between City and Oblast had ended as early as 1955, and settlements within the region were institutionally neglected. Filtzer points to some of the practical consequences, explaining, for example, that settlements in the region downstream of Moscow were polluted daily by around 500,000 cubic meters of waste [29]. The City was however interested in the Oblast as a territory for expansion, and there was a notion of a Greater Moscow, indicated in the Master Plan of 1971 which proposed a ring of satellite cities in the region beyond the closely regulated greenbelt [30]. The draft Master Plan of 1989 offered a regional consciousness in dealing with environmental threats, but it was an inopportune time to complete planning processes and to forge new institutional links. Early post-Soviet attempts to institutionally integrate the City and Oblast were scuppered by the Oblast's fear of domination by the City, and by the City's reluctance to share resources with its weaker neighbor.

The rapid expansion of Saint Petersburg and Moscow during the economic boom of the 2000s, happened in the absence of any formal mechanisms of institutional coordination. In both regions, the expansion of development across the City boundary into the Oblast, was intensified by the building of second homes (dacha) for summer residence. This amplified the existing problems of poorly coordinated transport systems, the lack of environmental protection along the urban edge, and disjointed bulk infrastructure systems [31].

Attempts to resolve the problem were further complicated by institutional jealousies and rivalries. The Oblasts, for example, resented the system of national taxation in which personal income tax is paid to the local authority within which an individual works rather than to the authority in which they reside. With mass commuting from the Oblasts into the Cities-including, in summer, from the dachas-this hugely disadvantages the Oblast. The City authorities in turn are critical of the poor management of growth by the Oblasts, and of the negative environmental spillovers into their territory. In the case of Saint Petersburg, for example, the Leningrad Oblast, needing a tax income, supported the largescale development of hazardous activities along the border of the city, including sewage 
processing, aluminum smelting, and waste landfill sites. Lobbying by the City government for a Federal law placing controls on development within $50 \mathrm{~km}$ of its boundary, failed [27].

The negative consequences of uncoordinated development were especially severe in the case of transport, with massive congestion developing across the City-Oblast borders during rush hour. In the case of Moscow this directly affected the functioning of Federal Government which was headquartered in the city center. In February 2011, the then Russian Prime Minister, Vladimir Putin, issued an Order for the establishment of a 'Coordination Council for Transport for Moscow and the Moscow Oblast', and this was followed by a similar Order for Saint Petersburg-Leningrad. The Coordination Councils are chaired by the Federal Minister of Transport and require the attendance of the respective Mayors and Governors. The improved coordination of regional transport infrastructure was indicated, for example, in the run-up to the 2018 FIFA World Cup and in the development of new infrastructure such as the Moscow Central Circle, a rail line through a largely derelict belt of heavy industry.

Formal linkage between City and Oblast is still restricted to the transport sector but there are now indications of experimental collaborations in other areas, as evident, for example, in a Joint Plan between Saint Petersburg and the Leningrad Oblast which incorporates a designated Zone of Mutual Interest as a spatial innovation. Russia's Federal Government has also moved fitfully towards requiring coordinated development within Urban Agglomerations (UAs). In 2019, Prime Minister Dmitry Medvedev approved a 'Spatial Development Strategy for the Russian Federation up to 2025' which identifies 20 UAs across Russia [32]. The institutional mechanisms for enabling integration within UAs are, however, still in an early phase of development.

The link between these emergent mechanisms of agglomeration-wide coordination and environmental sustainability remains tenuous. The sustainability crisis in Russia is deeply embedded within a national growth path that is shaped by a historical dependence on the country's vast reserves of oil and gas [33]. This presents severe limits to action at the scale of a city-region/UA [34]. The idea of the UA is itself a Soviet-era concept that reflects prior concerns with state-led industrial development. In Russia's established field of 'agglomeration studies' the UA is still understood as an economically functional unit, although there is a nod to concerns with environmental risk and safety [35]. However, recent experience offers some hope of mitigating action at least. The Joint Coordination Councils for Transport were motivated by growing popular discontent with road congestion but have brought sustainability benefits. There is also the prospect that gradually enhanced coordination along City-Oblast boundaries, may gradually strengthen the handling of environmental spillovers including water pollution, air quality, solid waste generation, and hazardous waste disposal.

\subsection{The Union of India}

India is of course a country facing massive sustainability challenges; not least in terms of the challenges of water security and air pollution which clearly cannot be resolved within existing jurisdictional boundaries. Whether there is any prospect for meaningful intervention at the scale of the city-region is a matter of debate.

India does have a history of metropolitan- and city region-type governance arrangements, with metropolitan-scale governance going back at least to 1961 when the State of West Bengal set up a 'Metropolitan Planning Organization' and a 'Council for the Coordination for Development' for the Calcutta Metropolitan Area, both funded by the New York-based Ford Foundation. This followed recommendations from the World Health Organization (WHO) and World Bank that dealing with Calcutta's water and sanitation crisis would require co-ordination across the urban region [36].

Metropolitan scale institutions diffused across the large cities in India although Delhi followed a different trajectory because of its capital city status. In the 1970s, metropolitan structures were standardized as Metropolitan Development Authorities (MDAs), but these structures were technocratic instruments of State governments with limited, if any, involve- 
ment of municipal authorities, and offered no platform for collaborative governance [37]. This reflected the political settlement which shaped post-independence India, which involved the mutual accommodation of national- and state-level interests, but with local interests and governance given very little attention.

In the 1980s, as a part reaction to the centralizing authoritarianism of Indira Gandhi's National State of Emergency, there was growing discourse around decentralized governance and the 73rd and 74th Constitutional Amendment Acts of the early 1990s provided the formal mechanisms for strengthening democracy and bureaucratic institutions at the local level. However, state-level interests were deeply entrenched, and the constitutional changes were implemented only very partially, with local governance remaining the stepchild of India's federal arrangement [37].

In the face of proliferating institutional arrangements from the 1990s, the MDA's gave up on the pretense of coordinated metropolitan planning and development, and focused on the profitable business of acquiring, developing, and selling off land, for real estate development [37]. There was however a provision in the 74th Amendment that State governments should set up Metropolitan Planning Committees (MPCs) for each of the eleven designated Metropolitan Areas across India and that two-thirds of the membership of these MPCs should be drawn from local corporations. This however directly challenged the interests of State government in controlling metropolitan development process and, as Sivaramakrishnan put it, "there are no takers for this prescription" [37]. Where MPCs were established for compliance purposes, they were allocated minor roles by the State governance.

Delhi, as indicated, had a different trajectory and is the only city which is formally considered to be part of a city-region. The hugely influential Delhi Development Authority (DDA) was the ostensible equivalent of the MDAs in the other metropolitan cities, but it was, and still is, tightly controlled by Union or Federal Government and not by the quasi-State government for the National Capital Territory of Delhi (NCT of Delhi). However, beyond the NCT of Delhi, and encompassing a vast swathe of territory, a National Capital Region (NCR) was delineated in 1985, with its planning assigned to a National Capital Region Planning Board (NCRPB) comprising senior officials from Union and State governments [38].

The idea of an NCR goes back to the 1950s and the concern of the post-independence elite, including Prime Minister Nehru, that the growth of Delhi should be carefully regulated to sustain the order and symbolic power of the national capital city. The big spatial concept was of 'counter-magnet cities' in a girdling belt of more than $200 \mathrm{~km}$ radius from Delhi that would absorb growth diverted from the capital. It was a hyped-up version of Garden City plans in the UK. The states with territory which fell within the NCR-the NCT of Delhi, Haryana, Uttar Pradesh and Rajasthan - were however resistant to Union encroachment into state planning powers and suspicious of the intentions behind the NCR. It took around three decades for the States to accept legislation setting up the NCRPB.

Once established, the NCRPB was given significant powers over planning and regulating growth, and a Regional Plan was released in 1988 [38]. In practice, however, the NCRPB was a weak structure, undermined by its very limited professional capacity, continued resistance from the states, and conflicting interests among its members. Therefore, for example, the Planning Board objected to the proposals by the DDA to support higher density in the core city of Delhi, and even to further growth of the inner ring satellite cities such as Noida and Gurgaon in Uttar Pradesh and Haryana [39]. It was only the interests of far-flung Rajasthan, for example, which coincided with the vision for 'counter magnets' in the Regional Plan. The weakness of the structure was highlighted in 2014 when the High Court in Delhi delivered a scathing judgement, criticizing the NCRPB for its failure to implement, and advising government to dissolve the Board if it was unable to enforce its Regional Plan [40].

Nevertheless, as India's cities have grown, so environmental threats have been increasingly evident, and more difficult to ignore in metropolitan- and city-region scale planning. 
Conflicts between development and environmental sustainability imperative have also intensified, forcing structures such as the NCRPB to play a mediating or advocacy role, although often only when the High Courts have intervened.

The NCRPB's Regional Plan, for example, designated the Aravallis Hills on the edges of Delhi in the State of Haryana, as an Environmental Conservation Zone (ECZ) because of their natural beauty and water-producing capacity. The developer-friendly Haryana government refused to accept this provision and unilaterally issued construction permits to real estate developers. After a long dispute, the Board eventually capitulated allowing individual states to determine the extent of ECZs in their territory. This in turn prompted the Supreme Court of India to insist that the NCRPB fully implement its Regional Planning and enforce the plan's designation of the ECZ [41,42].

Currently, the most politically contentious environmental concerns are air pollution and water security. The WHO has rated Delhi as the most air polluted large city in the world, while the Supreme Court of India has lambasted political leadership across all levels, saying that "Delhi has become worse than narak (hell)" [43]. In doing so, the Supreme Court fingered the lack of inter-governmental coordination as one of the critical reasons for the crisis, referring to the poor working relations between the politically opposing NCT of Delhi and the Union government, and the failure of the states of Haryana, Uttar Pradesh, Uttarakhand, and Punjab to stop the stubble burning which significantly aggravates pollution in the national capital [43].

The mounting crisis around air pollution was long underplayed by political leadership across the scales of government, and understated in plans, including those prepared by the NCRPB, but this is changing. The NCRPB finally responded in 2016, calling a Special Meeting to discuss air pollution, and ordering State government to present action plans for curbing pollution, even if this meeting was called following an order of the High Court of Delhi [44].

A significant challenge for the NCRPB in responding is that the 'problem area' does not relate meaningfully to its jurisdictional boundaries. The NCR was established as the territory into which the further growth of Delhi could be diverted and was not designed to reflect an existing spatial or environmental logic, or even an economic functionality. Much of the NCR is rural and low density in Indian terms and is not the obvious source of the pollution crisis facing Delhi. The real urban corridor, the actual source of pollution, is un-recognized in urban policy and planning. It is the vast corridor of dense urban and rural development along the Indus Valley, connecting through Delhi to Lahore in Pakistan. It highly unlikely, given transnational tensions, and inter-state rivalries, that collaborative inter-jurisdictional governance arrangements to address common sustainability concerns will emerge along this corridor.

Apart from air pollution, water is the other critical sustainability concern at the regional scale. Inter-state tensions around water are common across India but extreme in the case of Delhi. Nearly 70 percent of Delhi's water comes from the Yamuna River which flows in from the State of Haryana but, with both Haryana and Delhi being water scarce with high demand, there is continual tension.

In 1996, an agreement was reached between the Delhi and Haryana governments to construct the Munak Canal to carry water from the upper reaches of the Yamuna in Haryana directly to the capital. The canal was opened in 2012 but inter-state disputes have continued with Haryana periodically shutting water supply to Delhi, ostensibly over disagreement around payment, but clearly related to Haryana's own water scarcity. In 2016, the canal was blocked during a local uprising in Haryana and the Indian army was called into restore supply to Delhi. Political division between the Delhi and Haryana state governments have exacerbated tension in the recent past, and the High Court of Delhi has had to intervene to broker a series of interim agreements to keep the water flowing [45,46].

The High Court has effectively served as an instrument of city region governance in the absence of functional collaborations around water security. In a similar way, for example, the National Green Tribunal has had to intervene in the absence of sustained 
coordination around controls over water quality. The pollution of the Yamuna River reached such as degree of severity that professional witness in the courts referred to the river as serving only as "a drain carrying sewage, domestic waste as well as industrial and trade effluents" [47]. With joint action across jurisdictional boundaries, weak and sporadic at best, the Tribunal has demanded action and threatened penalties.

\subsection{People's Republic of China}

Unlike India, city region-scale governance in China is in fact rationalised in terms of the requirements for environmental sustainability. The material context for city region governance in China is the massive expansion of urban areas since the 1980s. Between 1980 and 2015, China's cities accommodated an additional 590 million people, with levels of urbanisation increasing from 19 percent to 56 percent. While the urban population increased fourfold within a generation, the physical extent of urban areas increased sixfold [48].

The horizontal expansion of urban agglomerations across long-established jurisdictional boundaries created immense problems of co-ordination in a governmental system which has been vertically oriented from the early dynasties of Imperial rule. The challenges of co-ordination emerged first in the mega urban agglomerations mushrooming along the east coast of China in the 1980s and 90s, but soon followed in the interior as the experimental reforms in the east were extended nationwide.

The turn to a form of urban regional governance was indicated with the launch of China's 11th Five Year Plan (2006-2010). The Plan identified 'city clusters' and referred to the importance of inter-jurisdictional cooperation within their still vaguely defined territories. Despite some exaggerated reporting in the global media of China's intention to build massive new cities, the clusters were in fact intended to support the decentralisation of activity from large cities into regional networks of smaller- and medium-sized cities [49]. They represented an attempt by China's national political elite to manage continued urbanisation in a way that would not produce mega urban concentration.

The idea of city clusters came in fact from the notion of 'economic circles', referring to zones of economic influence where coordinated action was required to improve overall competitiveness. The concept was borrowed from Japan and has been applied by China to range of spatial scales, from 'Great Economic Circles' at the transnational scale to facilitate the integration of parts of China into wider regional economies, to zones surrounding individual cities as small as Lhasa in Tibet [50]. In the mix, the idea of the economic circles has meshed with Western-inspired notion of city region governance.

While the economic circle, or city cluster, has been taken up in national planning processes, there is considerable variation across China in the ways in which the concept is applied. National government has played a very strong role in managing the planning and governance processes in the region including and surrounding the national capital, Beijing. The development of China's National Capital Economic Circle, known less formally as Jing-Jin-Ji (or JJJ), was elevated as a national priority in the 13th Five Year Plan (20162020) and has been championed at the highest level by President Xi Jingping [51]. Xi's flagship initiative is the creation of the Xiong'an New City intended to absorb non-essential functions from Beijing and help cap the population of the capital at 23 million people [52].

The Greater Bay Area (GBA) in the far south of China has a different relationship to the political centre of China. Since the late 1970s, it has served as "experimentation ground" for China's reform, most notably with the development of the Shenzhen Special Economic Zone [53]. The GBA has seen a succession of regional plans and coordination forums, with different combination of bottom-up and top-down initiative, although intense inter-urban rivalries often limit cooperation, except, possibly, in the Guangzhou-Foshan-Zhaoqing Metropolitan Area where collaboration has evolved from a long history of cultural and governmental association. The complicated inter-governmental and political relationship between mainland China, including the Guangdong Province, and the Hong Kong and Macau Special Administrative Regions (SPRs), is a critical factor in the development of city-regionalism in the GBA. City-regionalism has been promoted as a practical means 
of integrated but is also viewed with suspicion for its political underpinnings, especially from within Hong Kong. Nevertheless, the Shenzhen- Hong Kong interface is marked by multiple forms of cross-border collaboration.

The Yangtze River Delta (YRD) provides the strongest example of intra-regional collaboration among the major city clusters in China. This may be historically rooted in the shared histories and cultural resources of this $\mathrm{Wu}$ Chinese speaking region. It may also have emerged from the practicalities of governance within the intensely interlinked network of towns and cities across the YRD. Although the YRD is split across three provinces, and the municipality of Shanghai (which has provincial-level status), there are strong threads of inter-municipal cooperation. There is, for example, an Annual Meeting of Mayors across the YRD which is structured to include annual cooperation agreements which are implemented through the coordination offices in each of the 30 plus municipalities.

There is little doubt that the emergent, and spatially varied, system of city regionalscale governance in China is the outcome of multiple, intersecting interests. National elites are concerned, for example, to ensure that China's growth is managed to minimise risks including those associated with large concentrations of urban population. However, the environmental motivation for city region governance is clearly part of the mix. While the environmental justification may obscure political motivations for regional solutions, sustainability concerns are themselves political as the deteriorating environmental quality, which followed in the wake of China's decades-long economic boom, is a potential wellspring of popular discontent.

The rebalancing away from an economic policy of growth at almost all costs has taken time. While China in the 1980s and 90s, under the leadership of Deng Xiaoping and Jiang Jemin, pursued policies overwhelming concerned with releasing the 'productive forces' of society, General Secretary Hu Jintao called for a rebalancing of development in the interests of a 'harmonious socialist society' with more attention given to social equity and environmental considerations. However, he was a low-key leader, and it took the authority of General Secretary Xi Jingping after 2012 to put "ecological progress" firmly at the centre of state policy [54].

Taking their cue from the national leadership, regional and local actors have incorporated environmental sustainability as a central element within the plans for urban agglomerations. The orientation, however, is towards "ecological modernisation" with the focus of the plans on improving environmental quality in the core cities designated for world class status. For Beijing and Shanghai, for example, polluting industries have been moved out of the municipal area, contributing to gradually improving air quality, but this has come at the expense of air quality in regional cities which have received the decentralising industry. A key legitimation for the emphasis in city cluster plans for capping the size of their core cities is the notion of ecological carrying capacity, and there are many technical studies in Chinese literature which attempt to quantify the limits $[55,56]$.

The city clusters in China have vaguely defined boundaries and a wide territorial reach, allowing for a flexibility in responses, but complicating attempts to institutionalise governmental collaborations. The challenge of air pollution, for example, does require co-ordinated response over a wide territory but the air pollution plume for Beijing, often extends far beyond the widely defined National Capital Region to incorporate much of north and central China, and includes pollution sources from rural areas and from cities remote from the core region. Ensuring water security for Beijing also requires interventions with a reach far beyond the National Capital Region: China's massive South-North Water Diversion Project transfers water from as far south as the Yangtze River in central China through a massive network of water infrastructures [57]. Even the extensively defined National Capital Region is too territorially confined to address the water requirements of Beijing and its neighbouring cities.

While sustainability concerns are tied up with other agendas and may be used to rationalise these agendas, the current attention given to the natural environment in the planning and management of city-regions in China is an important antidote to decades of 
neglect. However, city-region governance is clearly not sufficient to address the scale of China's urban environmental challenges.

\subsection{Republic of South Africa}

In 2004, the Premier of Gauteng Province, South Africa's economic powerhouse launched the idea of the Gauteng City-Region (GCR), drawing liberally on a discourse of competitive regionalism. He was, however, speaking in the context of a post-apartheid imperative to reverse the legacies of a divided past, and in the context of what may be the world's most unequal urban agglomeration. The notion of a competitive city-region was controversial within the Premier's party, the African National Congress (ANC), and was soon adjusted to emphasise concerns with inclusion and social equity [58].

The idea of Gauteng as a city-region had taken on a post-apartheid intonation but it was the latest in a long history of regionalist responses to the spatial complexity of the urban agglomeration that had developed since the late nineteenth century around the world's richest gold mines. From the early years, after the gold discoveries in 1886, there had been attempts to achieve a level of coordination in this spatially complicated, urban region. In the early twentieth century there was, for example, a Witwatersrand Provisional Joint Committee and in the 1930s the idea of a Randopolis galvanised joint planning between municipalities for a few years. The idea of a Pretoria-Witwatersrand-Vereeniging (PWV) urban region emerged in the 1950s but regionalist responses came up against the centralising actions of the apartheid regime. However, in the 1980s, the apartheid region turned towards regionalism to resolve a deepening socio-spatial crisis. Race-based institutional and spatial arrangements had created impossible conditions for urban management and coordinated the delivery of infrastructure systems. The government therefore set up Regional Services Councils (RSCs) as local federative structures for the delivery of infrastructure across racially separated authorities. However, even as the RSCs started work, South Africa's political landscape changed dramatically, allowing for a far more fundamental change; that is, the amalgamation of the previous racially defined and fragmented local authorities into large, consolidated non-racial authorities [59,60].

In 2000 single-tier metropolitan authorities were set up for South Africa's largest urban agglomerations. In Gauteng Province (the old PWV) three metropolitan municipalities were established-Johannesburg, Tshwane (or Greater Pretoria) and Ekurhuleni (or the East Rand). In the case of Johannesburg, the single metropolitan structure was an amalgamation of 15 previous racially structured local authorities. However, this conjoining did not fully resolve the challenges of collective action across the Gauteng urban agglomerations: Although the new national constitution of 1996 committed the three spheres of government-national, provincial, and municipal-to the principles of 'co-operative governance', there was jostling for institutional position between the spheres, and weak coordination across metropolitan boundaries. It was within this context that the provincial Premier outlined his vision for a seamless GCR, although it was a vision received warily by some metropolitan authorities which suspected that the GCR was a ploy to strengthen the position of provincial government vis-à-vis the metropolitan cities. A decade-and-a-half later the idea of the GCR is still propagated by provincial leaders, with varying degrees of buy-in from metropolitan and other governance actors but there has been little progress in institutionalizing the vision, except for the creation of a knowledge base for the cityregion through the establishment of the Gauteng City-Region Observatory (GCRO). The significance of the GCR may still rest in future developments [60-64].

The driving imperatives of the GCR were the needs to deliver on post-apartheid promises of job creation through inclusive economic growth, and to equalize access to infrastructure and services. Environmental sustainability did not feature strongly, if at all. However, in the early days of development along the mining belt, the provision of environmental services led to the creation of the only sustained long-term city-region wide structure, the Rand Water Board. With the development of the mines, and the urban areas around them, an adequate supply of potable water was a pressing concern: ad hoc 
attempts to provide water were failing, and water-based disease was spreading. One of the first acts of the new British administration after the South African War (1899-1902) was to set up a special commission to investigate the water problem, and in 1904 the Rand Water Board was constituted with representation from newly created local councils and mining companies. With its local representation, the Rand Water Board was a platform of associational governance although only for the ruling white class. Over time, however, the Rand Water Board became increasingly technocratic in its structure and representation and was removed from the domain of local politics. In the post-apartheid era, the Rand Water Board is appointed by the National Minister of Water Affairs and has no direct relationship to any local governance actor $[60,65]$.

Currently, water security is a major concern for the GCR but water is a function of national government, and provincial and municipal structures can, seemingly, do little more than to pressure national government, and promote more efficiency in the distribution and use of water. However, as Woodhouse and Muller point out, in practice, water governance happens in networks and nested hierarchies, crossing scales. New territorialities are emerging because of the imperatives of water governance and some of these are regional. The 'regional' does however not necessary coincide with what is commonly known as the city-region. Woodhouse and Muller explain that "water supply to South Africa's Gauteng province and surrounding region, with a third of the country's population and much of its economic activity, comes from a system that taps four separate river basins" [66]. Air pollution in the GCR is moderately severe and while there are sources of pollution internal to the city-region, such as heavy industry in Ekurhuleni and the Vaal, and the private motor and paratransit, which account for the overwhelming bulk of trips, there are also sources external to the region. The Mpumalanga highveld, east of the GCR, ranks among the world's major $\mathrm{NO}_{2}$ and $\mathrm{SO}_{2}$ pollution hotspots because of its concentration of coal-fired power stations and petrochemical industries, and severely affects the GCR, depending on wind direction. The GCR can thus only partially address its air pollution through collaborations and interventions within the GCR.

Other matters of sustainable resource usage have slowly surfaced within a public discourse which is still strongly shaped by the memories and consequence of apartheid rule. There is a gradual synergising of concerns with sustainability, social justice, and the inclusive (job-creating) economy, around concepts such as 'environmental justice', but these discursive shifts often relate to the national policy domain or to very local initiatives [67]. They have not obviously cohered within thinking around the scale of the city-region, except in the work of the GCRO which offers a regional perspective on matters such as green infrastructure, the green economy, and toxic mine residue [68-70]. These studies provide a complex view on the nexus between sustainability and the city-region, showing how limited the connection has been historically, and how difficult the conundrums facing government are currently in applying sustainability policy at the scale of a city-region. Götz and Schäffler point out that the conundrums "are real policy dilemmas, arising from the way in which government itself is imbricated-through inherited expectations, assumptions, and institutional fixtures-with an old growth path" [70].

\section{Concluding Analysis}

The BRICS study reveal the limitations and possibilities of city regionalism in addressing sustainability concerns. The first limitation rests in the scantiness of the current practice of city-regionalism. The current structures of city-region governance are hardly adequate to the task of addressing the complex, cross-cutting concerns of environmental sustainability. There are no instances in the BRICS where there are functional, multi-facetted forms of city-region governance across all major urban regions. In Brazil, the fitful progress towards regional-scale collaboration is in apparent reverse; in Russia, meaningful collaborations in the two largest urban regions are limited to the transport sector; in India, city-region governance remains severely hamstrung by state-level interests; while in China and in 
South Africa, the discursive focus on 'city clusters' and 'city regions' has still to find a clear expression in governance arrangements.

A second limitation rests relates to the spatial scales at which sustainability concerns can be addressed. In the case of Russia, China and South Africa, the extreme carbon dependence of national economies can hardly be addressed by interventions at the scale of a city-region. There may be more space for regional interventions in China than in the other case as municipalities are empowered to provide their own electricity supply, and there is national support for changing the energy profile away from fossil fuels. In Russia, however, national support for a sustainable transition remains ambiguous while in South Africa a policy commitment to reducing carbon-dependence has not been matched by the necessary changes in institutions and regulations. Electricity-production remains overwhelming in the hands of a single national state-owned enterprise that is locked into a coal-based pathway.

The water sector is different and regional approaches to supply and distribution are more common. There is however often a significant disjuncture in the territorial requirements for water security and the delineation of city-regions for other purposes (for example, using criteria of economic linkage, commuting flows or contiguous urban footprints). The governance of water supply is generally constructed around river catchments and the demand for water from large urban agglomerations often requires the harnessing of water from more than one catchment, with complex technical arrangements for inter-basin transfers that extend territorially far beyond the reach of a city-region. In the case of the GCR in South Africa, water is sourced from as far as the Lesotho highlands in a grand transnational water transfer scheme while the massive South to North Water Diversion Project to support Beijing extends deep into central China. As the "ultimate survival good" [20], water security may compel regional-scale collaboration but it may also provoke intense conflict as in the case of the inter-state rivalries in India or, more locally, within the structures of water governance in the São Paulo Metropolitan Region.

Air pollution is another example of territorial mismatch. Urban agglomerations are the source of much of their own pollution and steps can be taken to clean their own backyards (for example, through a shift to public transport and stronger regulation of polluting industries). The most effective examples of sector-based city-region governance may, in fact, be in relation to the management of transport systems. In the case of the BRICS the Joint Councils on Transport Coordination in the Russian Federation are examples. However, there are many contexts where causes of air pollution are geographically expansive, and where more complex inter-scalar governance arrangements, and additional forms of horizontal coordination, may be required as a response. This is the case for Greater Delhi where air pollution is the outcome of interlocking rural and urban causes in the dense agglomeration of settlements crossing state and national boundaries in the $1700 \mathrm{~km}$ Indus Valley. In South Africa, prevailing winds draw into the GCR the severe $\mathrm{SO}_{2}$-related pollution from the mega cluster of coal-fired stations across the provincial boundary in Mpumalanga.

The third limitation relates to the politics of sustainability. Even where structures of city-region governance are in place, and sustainability concerns can be meaningfully addressed at the scale of the city-region, there is no guarantee that sustainability concerns will be addressed. Much depends on the configuration of power and interests within the city-region. Historically, sustainability concerns have not figured strongly in the agendas of the political elites in the BRICS nationally, and at regional- and city-scales. In Russia it does not pay the elites to shift from a growth path premised on cheap carbon-based energy. In China, the early reform era was characterised by a doctrine that may be described as growth at all costs, and the doctrinal commitment cascaded down the governmental hierarchy. In India, the developmental ideologies of the post-colonial elite supported industrialisation and the development of modern infrastructure such as large dams without evident concern for environmental consequences. In South Africa, post-apartheid state and society, the elites are under immense pressure to respond to the immediate economic and social consequences of apartheid, with far less pressure to address the mounting environmental crisis. 
There are tough constraints in forging a strong nexus between city-regionalism and sustainability, but there are also emergent possibilities revealed through the BRICS study which provide a platform for collaborative action in the future. Brazil has been on an uneven path towards stronger regional-scale collaboration and the current reversal will, hopefully, not prove permanent. Emergent practices including voluntary collaborations between municipalities, more formally structured metropolitan councils and regionally structured water committees provide a resource for future collaborations. Brazil has the advantage of non-carbon-based energy supply, but must still ensure integrated transport systems, water security for its largest cities, and improved environmental conditions in its favelas, or informal settlements.

The post-Soviet story in Russia is of the disintegration of regional-scale collaboration but there has been a recent return to partial, and sector-specific, forms of collaboration, that offers a demonstration effect for integration in other domains. The aggravation of severe road congestion, rather than an environmental commitment, goaded national authorities to compel regional actors to collaborate around transport, and the practical consequence of other types of environmental damage may produce new forms of regional-scale interaction.

In India, a succession of initiatives to support collaborations at metropolitan- and city-region have been undermined by powerful state interests and weakly developed local authorities. However, the politics is changing as the consequence of the environmental crisis for daily life is becoming increasingly unbearable. Whereas the shocking environmental conditions of India's slums previously affected the economically and political marginal, the severe levels of air pollution, and threats of water cuts, impact also on the lives of the elites. India's high courts have been the leading edge of a new environmentalism but, increasingly, other agencies of government will need to show their environmental commitment if they are to ensure sustained legitimacy and this may drive new regional-scale collaborations. In China, there has already been a significant shift towards and sustainability rationale for city-region scale collaborations. The devastating environmental consequence of a decades-long economic boom has compelled China's leadership to shore up its legitimacy by emphasising environmental reconstruction. In South Africa, environmental concerns are only gradually synthesising with developmental concerns but the recent work of the GCRO has brought environmental concerns into discussion around city-regionalism.

City-regionalism is not the panacea for sustainability and comes with multiple challenges but it does potentially play a productive role within a wider framing of interscalar governments which allows sustainability challenges to be addressed simultaneously through different forms of territorialisation. While historical evidence for meaningful action at the scale of the city-region is limited, the practical politics of addressing the consequences of environmental crisis may be gradually strengthening the nexus between city-regionalism and sustainability.

Funding: This research draws on a project funded by the Gauteng Provincial Government through the Gauteng City-Region Observatory and South Africa's National Research Foundation-NRF Grant No. 71194.

Data Availability Statement: The data that support the findings of this study are openly available in the following repositories: UNDP 2020 Human Development Data at http://www.hdr.undp. org/en/content/download-data; UN World Urbanisation Prospects 2018 at https:/ population. un.org/wup/; IMF Data at https:/ /www.imf.org/en/Data; and World Bank Open Data at https: //data.worldbank.org/.

Acknowledgments: The author acknowledge colleagues within the BRICS+ City Lab network who have provided both contextual insight for each country of study and logistical support when visiting the respective countries.

Conflicts of Interest: The author declares no conflict of interest. 


\section{References}

1. Kissinger, M.; Rees, W.; Timmer, V. Interregional sustainability: Governance and policy in an ecologically interdependent world. Environ. Sci. Policy 2012, 14, 965-976. [CrossRef]

2. Homsy, G.; Warner, W. Cities and Sustainability: Polycentric Action and Multilevel Governance. Urban Aff. Rev. 2015, 51, 46-73. [CrossRef]

3. Coutard, O.; Rutherford, J. Energy transition and city-region planning: Understanding the spatial politics of systemic change. Technol. Anal. Strateg. Manag. 2010, 22, 711-727. [CrossRef]

4. Dubbeling, M.; Santini, G.; Renting, H.; Taguchi, M.; Lançon, L.; Zuluaga, J.; De Paoli, L.; Rodriguez, A.; Andino, V. Assessing and Planning Sustainable City Region Food Systems: Insights from Two Latin American Cities. Sustainability 2017, 9, 1455. [CrossRef]

5. Janssen-Jansen, L.; Hutton, T. Rethinking the Metropolis: Reconfiguring the Governance Structures of the Twenty-first-century City-region. Int. Plan. Stud. 2011, 16, 201-215. [CrossRef]

6. Palmer, A.; Santini, G.; Dubbeling, M.; Renting, H.; Taguchi, M.; Giordano, T. Validating the City Region Food System Approach: Enacting Inclusive, Transformational City Region Food Systems. Sustainability 2018, 10, 1680. [CrossRef]

7. Orlando, F.; Spigarolo, R.; Alali, S.; Bocchi, S. The role of public mass catering in local foodshed governance toward self-reliance of Metropolitan regions. Sustain. Cities Soc. 2019, 44, 152-162. [CrossRef]

8. Scott, A.; Agnew, J.; Soja, E.; Storper, M. Global city-region. In Global City-Regions: Trends, Theory, Policy; Scott, A., Ed.; Oxford University Press: Oxford, UK, 2011; pp. 11-31.

9. Scott, A. City-regions reconsidered. In Environment and Planning A: Economy and Space; SAGE Publications: London, UK, 2019; Volume 51, pp. 554-580.

10. McCann, E.J. Framing space and time in the city: Urban policy and the politics of spatial and temporal scale. J. Urban Aff. 2003, 25, 159-178. [CrossRef]

11. Ward, K.; Jonas, A. Competitive City-Regionalism as a Politics of Space: A Critical Reinterpretation of the New Regionalism. Environ. Plan. A 2004, 36, 2119-2139. [CrossRef]

12. Jonas, A.; Ward, K. Introduction to a Debate on City-Regions: New Geographies of Governance, Democracy and Social Reproduction. Int. J. Urban Reg. Res. 2007, 31, 167-178. [CrossRef]

13. McGuirk, P. The Political Construction of the City-Region: Notes from Sydney. Int. J. Urban Reg. Res. 2007, 31, 171-187. [CrossRef]

14. Neuman, M.; Hull, A. The Futures of the City Region. Reg. Stud. 2009, 43, 777-787. [CrossRef]

15. Wheeler, S. Regions, Megaregions, and Sustainability. Reg. Stud. 2009, 43, 863-876. [CrossRef]

16. Addie, J.; Keil, R. Real Existing Regionalism: The Region between Talk, Territory and Technology. Int. J. Urban Reg. Res. 2015, 39, 407-417. [CrossRef]

17. UN-United Nations. World Urbanization Prospects, a Database of the Department of Economic and Social Affairs of the United Nations. Available online: https:/ / population.un.org/wup/ (accessed on 3 February 2021).

18. Robinson, J. Thinking cities through elsewhere: Comparative tactics for a more global urban studies. Prog. Human Geogr. 2016, 40, 3-29. [CrossRef]

19. French, J. Drowning in Laws: Labor Law and Political Culture in Brazil; The University of North Carolina Press: Chapel Hill, NC, USA, 2004.

20. Abers, R.; Keck, M. Muddy Waters: The Political Construction of Deliberative River Basin Governance in Brazil. Int. J. Urban Reg. Res. 2006, 30, 601-622. [CrossRef]

21. Ansell, A. Zero Hunger: Political Culture and Antipoverty Policy in Northeast Brazil; The University of North Carolina Press: Chapel Hill, NC, USA, 2014.

22. Ribeiro, L.; dos Santos, O., Jr. Large Cities and the Brazilian Social Question: Reflections about the 'State of Exception' in Brazilian Metropolises. In Inclusion, Collaboration and Urban Governance: Challenges in Metropolitan Regions of Brazil and Canada; McGee, T., Castro, E., Eds.; University of British Columbia: Vancouver, BC, Canada, 2010; pp. 47-64.

23. Klink, J. Development Regimes, Scales and State Spatial Restructuring: Change and Continuity in the Production of Urban Space in Metropolitan Rio de Janeiro, Brazil. Int. J. Urban Reg. Res. 2014, 37, 1168-1187. [CrossRef]

24. Costa, M.; Favarão, C.; Tavares, S.; Blanco, C., Jr. Do Processo De Metropolização Institucional A Implementação Do Estatuto da Metrópole: Dois Balanços, Suas Expectativas E Incertezas. In Brasil Metropolitano em foco Desafios à implementação do Estatuto da Metrópole; Marguti, B., Costa, M., Favarão, C., Eds.; Report of IPEA; Instituto de Pesquisa Economica Aplicada: Rio de Janeiro, Brazil, 2018; pp. 19-53.

25. Moore, S. Sub-National Hydropolitics: Conflict, Cooperation and Institution-Building in Shared River Basins; Oxford University Press: New York, NY, USA, 2018.

26. Empinotti, V.; Budds, J.; Aversa, M. Governance and water security: The role of the water institutional framework in the 2013-15 water crisis in São Paulo, Brazil. Geoforum 2019, 98, 46-54. [CrossRef]

27. Limonov, L. St. Petersburg Metropolitan Region: Problems of Planning Coordination and Spatial Development: “Regional Integration: Europe, the Mediterranean and the World Economy". In Proceedings of the 53rd Congress of the European Regional Science Association, Palermo, Italy, 27-31 August 2013; Available online: http:/ /www-sre.wu.ac.at/ersa/ersaconfs/ersa13/ ERSA2013_paper_00070.pdf (accessed on 5 March 2020).

28. Golubchikov, O. World-city-entrepreneurialism: Globalist imaginaries, neoliberal geographies, and the production of new St Petersburg. Environ. Plan. A 2010, 42, 626-643. [CrossRef] 
29. Filtzer, D. Standard of living versus quality of life: Struggling with the urban environment in Russia during the early years of post-war reconstruction. In Late Stalinist Russia: Society Between Reconstruction and Reinventions; Fürst, J., Ed.; Routledge: London, UK; New York, NY, USA, 2006; pp. 81-102.

30. Colton, T. Moscow: Governing the Socialist Metropolis; The Belknap Press of the Harvard University Press: London, UK; Cambridge, MA, USA, 1995.

31. Phelps, N. The political economy of place at the post-socialist urban periphery: Governing growth on the edge of Moscow. Trans. Inst. Br. Geogr. 2011, 36, 425-440.

32. Government of the Russian Federation. Spatial Development Strategy for the Russian Federation for the Period up to 2025, Government Gazette, 13 February, No. 207-p. Available online: http://static.government.ru/media/files/UVAlqUtT08o6 0RktoOX122JjAe7irNxc.pdf (accessed on 28 November 2020).

33. Mol, A. Environmental Deinstitutionalization in Russia. J. Environ. Policy Plan. 2009, 11, 223-241. [CrossRef]

34. Tynkkynen, N. Prospects for ecological modernization in Russia: Analysis of the policy environment. Demokratizatsiyai 2014, $22,575-603$.

35. Lappo, G.; Lyubovnyi, V. Largest Urban Agglomerations in Russia at the Beginning of the 21st Century: Status, Problems, and Approaches to Solving Them. Reg. Res. Russ. 2011, 1, 34-43. [CrossRef]

36. Bhattacharya, M. Government in Metropolitan Calcutta. Indian J. Public Adm. 1965, 11, 702-720. [CrossRef]

37. Sivaramakrishnan, K.C. Revisiting the 74th Constitutional Amendment for Better Metropolitan Governance. Rev. Urban Aff. 2013, $48,86-94$.

38. NCRPB National Capital Region Planning Board. Available online: http:/ / ncrpb.nic.in/ (accessed on 22 February 2021).

39. Banerjee, T. Role of Indicators in Monitoring Growing Urban Regions, The Case of Planning in India's National Capital Region. J. Am. Plan. Assoc. 1996, 62, 222-235. [CrossRef]

40. Rajput, V. Law Buried Under Urbanisation, Hindustan Times. 23 July 2014. Available online: https:/ / www.hindustantimes.com/ noida/law-buried-under-urbanisation/story-68NwhaPaJDTqVcLA9DDN1K.html (accessed on 30 September 2020).

41. Ministry of Housing and Urban Affairs. Aravallis to Be Delineated in the Entire NCB, Press Release. 4 December 2017. Available online: http:/ / pib.nic.in/newsite/PrintRelease.aspx?relid=174084 (accessed on 3 July 2020).

42. Sinha, N. Saving the Aravallis from Gurgaon. The Hindu. 28 October 2017. Available online: https://www.thehindu.com/scitech/energy-and-environment/saving-the-aravallis-from-gurgaon/article19932597.ece (accessed on 29 October 2017).

43. Choudhary, A. Delhi Worse than Hell, People Are Living in Gas Chamber: SC. The Times of India. 26 November 2019. Available online: https: / timesofindia.indiatimes.com/city/delhi/delhi-worse-than-hell-people-are-living-in-gas-chambersc/articleshow /72232825.cms (accessed on 22 February 2021).

44. NCRPB. Agenda and Minutes of a Special Meeting of the National Capital Region Planning Board, 20 December, New Delhi. Available online: http:/ /ncrpb.nic.in/archive.html (accessed on 20 October 2020).

45. Chandler, A. A Battle Over Caste Spills into Delhi's Water Supply. The Atlantic. 22 February 2016. Available online: https: //www.theatlantic.com/international/archive/2016/02/delhi-protestors-water/470364/ (accessed on 22 February 2021).

46. Bhaduri, A. Two States, a Canal and a River. India Water Portal. 17 May 2016. Available online: https:/ / www.indiawaterportal. org/articles/two-states-canal-and-river (accessed on 22 February 2021).

47. National Green Tribunal. Manoj Mistra vs Union of India, National Capital Territory of Delhi, Delhi Development Authority and Others. 13 January 2015. Available online: http://delhi.gov.in/wps/wcm/connect/cd279c80473145b0bbf3fb825d7a2a20/6-2012 \%28PB-I-Judg\%29OA-13-1-2015.pdf?MOD=AJPERES\&lmod=-287594179 (accessed on 20 May 2020).

48. Harrison, P.; Yang, Y. Drivers of density change: The case of Beijing, China. In Densifying the City: Global Cases and Johannesburg; Rubin, M., Todes, A., Harrison, P., Appelbaum, A., Eds.; Edward Elgar: London, UK, 2021; pp. 93-102.

49. NDRC. The 11th Five-Year Plan: Targets, Paths and Policy Orientation. Available online: http://www.gov.cn/english/2006-03/ 23/content_234832.htm (accessed on 11 March 2019).

50. Wei, W.; Zhao, G. Research on the patterns of Japanese metropolitan circles: A literature review. Contemp. Econ. Jpn. 2005, $140,40-45$.

51. NDRC. The 13th Five Year Plan for Economic and Social Development of the People's Republic of China, 2016-2020. Available online: http:/ / en.ndrc.gov.cn/newsrelease/201612/P020161207645765233498.pdf (accessed on 11 March 2019).

52. Wong, F. Xiong'an New Area: President Xi's Dream City, China Briefing. 26 March 2019. Available online: https://www.chinabriefing.com/news/xiongan-new-area-beijing-tianjin-hebei/ (accessed on 22 February 2021).

53. Chen, X.; de'Medici, T. From a fishing village via an instant city to a secondary global city" The "miracle and growth pains of Shenzhen special economic zone in China. In Rethinking Global Urbanism: Comparative Insights from Secondary Cities; Chen, X., Kanna, A., Eds.; Routledge: London, UK; New York, NY, USA, 2012; pp. 105-126.

54. Xi, J. The Governance of China; Foreign Languages Press: Beijing, China, 2018.

55. Zhang, Y.; Chen, M.; Zhou, W.; Zhuang, C.; Zhiyun, O. Evaluating Beijing's human carrying capacity from the perspective of water resource constraints. J. Environ. Sci. 2010, 22, 1297-1304. [CrossRef]

56. Zhou, D.; Zhang, Z.; Shi, M. Where is the future for a growing metropolis in North China under water resource constraints? Sustain. Sci. 2015, 10, 113-122. [CrossRef]

57. Kattel, G.; Shang, W.; Wang, Z.; Langford, J. China's South-to-North Water Diversion Project Empowers Sustainable Water Resources System in the North. Sustainability 2019, 11, 3735. [CrossRef] 
58. Shilowa, M. Developing Gauteng as a Global Competitive City Region. Umrabulo. 3rd Quarter. Available online: http: //www.anc.org.za/docs/umrabulo/2006/umrabulo27.html (accessed on 30 March 2019).

59. Cameron, R. Central-Local Financial Relations in South Africa. Local Gov. Stud. 2002, 28, 113-134. [CrossRef]

60. Mabin, A. The Map of Gauteng: Evolution of a City-Region in Concept and Plan. GCRO Occasional Paper 05. Available online: http:/ / wiredspace.wits.ac.za/handle/10539/16851 (accessed on 22 February 2021).

61. Greenberg, S. The Gauteng City-Region: Private and Public Power in the Shaping of the City. Politikon 2010, 37, 107-127. [CrossRef]

62. OECD. OECD Territorial Reviews: The Gauteng City-Region, South Africa; OECD Publishing: Paris, France, 2011.

63. Gotz, G.; Wray, C.; Mubiya, B. The 'thin oil of urbanisation'? Spatial change in Johannesburg and the Gauteng city-region. In Changing Space, Changing City: Johannesburg after Apartheid; Harrison, P., Gotz, G., Todes, A., Wray, C., Eds.; Wits University Press: Johannesburg, South Africa, 2014; pp. 42-62.

64. Harber, J.; Joseph, K. Institutionalising the Gauteng City Region, GCRO Provocations \#03. Available online: http:/ /www.gcro.ac. $\mathrm{za} /$ media/reports/Provocation_Institutionalisting_the_GCR.pdf (accessed on 30 October 2020).

65. Tempelhoff, J. Rand Water and the Transition to a Multiracial Democratic South Africa 1989-1994. Afr. Hist. Rev. 2004, 36, 79-106.

66. Woodhouse, P.; Muller, M. Water Governance-An Historical Perspective on Current Debates. World Dev. 2017, 92, 225-241. [CrossRef]

67. Zander, S.; Venter, C.; Shackleton, M.; Van Staden, F.; Selomane, O.; Masterson, V. Green Apartheid: Urban green infrastructure remains unequally distributed across income and race geographies in South Africa. Landsc. Urban Plan. 2020, $203,103889$.

68. Bobbins, K. The legacy and prospects of the Gauteng City-Region's mining landscapes. Sustain. City 2013, 8, 1363-1373.

69. Bobbins, K.; Culwick, C. Green growth transitions through a green infrastructure approach at the local government level: Case study for the Gauteng City-Region. J. Public Adm. 2015, 50, 32-49.

70. Götz, G.; Schäffler, A. Conundrums in implementing a green economy in the Gauteng City-Region. Curr. Opin. Environ. Sustain. 2015, 13, 79-87. [CrossRef] 